\title{
The effect of milling on proteins in model Queso Fresco cheeses
}

\author{
Moushumi Paul, Alberto Nuñez, Diane Van Hekken
}

Eastern Regional Research Center, Agricultural Research Service, US Department of Agriculture, Wyndmoor, USA

Email: moushumi.paul@ars.usda.gov

Received 13 October 2011; revised 23 November 2011; accepted 29 December 2011

\begin{abstract}
Raw milk Queso Fresco (QF) made in Mexico contains contaminating bacterial strains that are not permitted in US foods. There is interest in developing a pasteurized milk version of Mexican Queso Fresco to be sold in the US. Milling is one of many manufacturing factors that may influence protein integrity. The aim of this study is to assess the effect of milling procedures on protein composition and cheese functional properties in a model QF, made without starter cultures. Mass spectrometric and gel electrophoretic analyses of aged milled cheeses show minimal changes in protein content without differences among the milling techniques. In these novel QF-like cheeses, eight weeks of aging, regardless of milling type, results in cheeses that is very similar to the non-aged samples. Aged cheeses with minimal proteolysis imply an extended shelf life and therefore, model cheeses from this study, relative to Mexican raw milk cheeses, would stay fresher in American households and supermarkets longer.
\end{abstract}

Keywords: Queso Fresco; Cheese Milling; Proteolysis; Mass Spectrometry

\section{INTRODUCTION}

Queso Fresco (QF) is a high-moisture fresh unripened cheese that is made in Mexico and other Latin American countries from raw milk [1,2]. Because the milk used to make the cheese is not pasteurized, there are native bacterial microflora present during QF manufacture from raw milk [3]. These strains of bacteria, while imparting some potentially important flavors and overall textural effects to the cheeses, are not suitable for consumption according to US standards for food quality. Because these cheeses are so moist and have a $\mathrm{pH}$ above 6.0 that supports the growth of a number of spoilage organisms and pathogenic bacteria, such as Listeria monocytogenes, there is significant interest in developing methods for the production of cheeses that are similar in taste, texture and overall sensory qualities to native, traditional QF, using pasteurized milk $[2,4,5]$. This work has yielded protocols that can be used to generate a QF-type cheese made from pasteurized and homogenized milk that does not utilize starter cultures [6].

A milling step is traditionally added to the QF cheese making process where the cheese curd is ground into small pieces to ensure crumbliness. There have been some studies that have monitored the effects of milling and $\mathrm{pH}$ on the chemical composition, proteolysis and functional properties in mozzarella cheeses $[7,8]$. It was noted that milling $\mathrm{pH}$ affected cheese $\mathrm{pH}$ and titratable acidity, but had little to no affect on proteolysis and chemical composition. However, when milling $\mathrm{pH}$ was tested in melted versus unmelted cheese, the hardness, meltability, viscosity, and free oil formation were affected in unmelted Mozzarella cheese. While some studies have focused on Hispanic-style cheeses, research has mostly been directed at sensory characterization $[9,10]$. Little has been studied, however, about the effects of different milling techniques on the overall protein composition of Hispanic-style cheeses and even less is known about these effects in Queso Fresco.

While the inclusion of a milling step can sometimes be advantageous, its incorporation into the cheese-making process introduces an additional potential source of contamination. In the case of QF, the native protocols for cheese-making include an additional milling procedure. It is important, however, to determine the overall merits of having this step included in production compared to the risks brought on by the increased susceptibility of the process to contamination by spoilage or pathogenic bacteria. Ongoing work is currently aimed at determining the effects of the size of fine milling on the overall quality traits of four model QF cheeses prepared using various milling techniques and stored at $4^{\circ} \mathrm{C}$. This paper specifically describes the effect of these four different milling procedures on the overall protein content within the model QF cheese matrix. 


\section{MATERIALS AND METHODS}

\subsection{Cheese Making}

QF was manufactured in duplicate from raw milk obtained locally according to a published protocol [11]. Each batch of cheese was prepared from $180 \mathrm{~kg}$ of milk that had been standardized to $3.5 \% \mathrm{wt} / \mathrm{wt}$ fat, homogenized at 6.9/3.4 MPa and then pasteurized at $72^{\circ} \mathrm{C}$ for 15 s. Milk was adjusted to $32^{\circ} \mathrm{C}$ in a cheese vat (Kussel Equipment Co., Watertown, WI, USA). Calcium chloride $\left(\mathrm{CaCl}_{2}\right)$ was added to the milk to a final concentration of $0.1 \%$ wt/wt; no starter culture was used. Chymosin (130 mL/1000L milk; CHY-MAX 73863, Chr. Hansen. Inc., Milwaukee, WI, USA) was added to coagulate the milk, and after $30 \mathrm{~min}$ the coagulated curd was cut into $1-\mathrm{cm}$ cubes. The temperature was raised to $39^{\circ} \mathrm{C}$ and the curd was cooked for $30 \mathrm{~min}$. Approximately 2/3 of the whey was drained from the vat and then dry salt ( $2.3 \mathrm{~kg})$ was added in three applications and mixed into the slurry for a total of 20 minutes. The rest of the whey was drained and the curd trenched. When the curd reached $\mathrm{pH}$ 6.3, it was removed from the vat, and chilled to $<21^{\circ} \mathrm{C}$. Chilled curds were finely milled using either a Bosch universal 6610UC/01 FD (Robert Bosch Hausgeräte GmbH, Dillingen, Germany) or a Waring Pro MG800 (Waring Pro East Windsor, NJ, USA) meat grinder. Milling treatments included: 1) no milling and immediately packed into molds; 2) curd was passed through the Bosch meat grinder without a blade; 3 ) curd was passed through the Bosch meat grinder with a small bore blade $(6.3 \mathrm{~cm}$ diameter blade with $180.7 \mathrm{~cm}$ holes); and 4) curd was passed through the Waring meat grinder with a large bore blade (6.3 $\mathrm{cm}$ diameter with $51.4 \mathrm{~cm}$ holes). The curd from each treatment was packed separately into molds and stored overnight at $4^{\circ} \mathrm{C}$. Each cheese was then removed from the mold, divided into 3 blocks, vacuum packaged, and stored at $4^{\circ} \mathrm{C}$. One block from each milling treatment was removed for testing after 1,4 , and 8 wk of storage.

\subsection{Water-Soluble Protein Extraction}

For each sample of Queso Fresco, water-soluble proteins were extracted in the following manner [12]: $5 \mathrm{~mL}$ of extraction buffer (0.166 M Tris, $1 \mathrm{mM}$ ethylenediaminetetraacetic acid (EDTA), $\mathrm{pH}$ 8.0) was added to $2 \mathrm{~g}$ of cheese. This mixture was homogenized by sonication for $6 \mathrm{~min}$. To this mixture, $5 \mathrm{~mL}$ of $7 \%$ sodium dodecyl sulfate (SDS) was added and further sonicated for $3 \mathrm{~min}$. While on ice, to this mixture was added $2 \mathrm{~mL}$ of $10 \mathrm{~mm}$ dithiothreitol (DTT) and the solution stirred at $0^{\circ} \mathrm{C}$ for 15 min. The resulting solution was centrifuged at 30,000 $\mathrm{g}$ for $1 \mathrm{hr}$ at $4^{\circ} \mathrm{C}$. The supernatant was filtered and lyophilized to yield the water-soluble protein extract used in subsequent experiments.

\subsection{Protein Distribution (SDS-PAGE)}

Electrophoresis was conducted as described by Van Hekken et al. [13] to analyze the protein distribution. Water-soluble proteins were extracted for SDS-PAGE from samples that had been stored at $-35^{\circ} \mathrm{C}$. Proteins were separated on $20 \%$ homogenous gels using the PhastSystem (American Pharmacia Corp., Piscataway, NJ, USA). After staining with Coomassie blue, gels were scanned with a Molecular Dynamics Model 375 Personal Densitometer (SI, Sunnyvale, CA, USA) and protein distribution calculated using ImageQuant (version 4.2, Molecular Dynamics). Each lane was analyzed in duplicate and major bands were identified as $\alpha_{\mathrm{s} 1}$-casein (CN), $\alpha_{\mathrm{s} 2}-\mathrm{CN}, \beta-\mathrm{CN}, \kappa-\mathrm{CN}$ (f1-105), and $\alpha_{\mathrm{s} 1}-\mathrm{CN}(\mathrm{f} 25-199)$. Casein fragments were divided according to molecular mass ranges (20 - $18.5 \mathrm{kDa}, 15$ - $18 \mathrm{kDa}$ and 10 - $14 \mathrm{kDa}$ ). Peptides smaller than $10 \mathrm{kDa}$ were not tracked because of migration off the gel.

\subsection{Protein Extraction for Mass Spectrometric Analysis}

Water-soluble proteins were extracted using a protocol adapted from multiple cheese protein studies [14-16]. Milli-Q ${ }^{\circledR}$ water (5 mL) was added to grated cheese sample (5 g) and the mixture was homogenized by sonication for $6 \mathrm{~min}$. More water was added (5 mL), and the mixture was further homogenized by sonication for $6 \mathrm{~min}$. The homogenate was stirred at room temperature for 30 min, and then centrifuged at $26,000 \mathrm{~g}$ for $60 \mathrm{~min}$ at $4^{\circ} \mathrm{C}$. The supernatant was filtered through a Whatman no. 1 filter paper and lyophilized to yield the water-soluble protein extract used in subsequent experiments.

\subsection{Mass Spectrometry Analysis}

Peptides resulting from trypsin digestion of the gel bands and UPLC spotted plates were subjected to analysis using a Matrix-assisted laser desorption ionization mass spectrometry with automated tandem time of flight fragmentation of selected ions (MALDI-TOF/TOF) with a 4700 Proteomics Analyzer mass spectrometer (Applied Biosystems, Framingham, MA) in the positive reflectron mode. Spectra were obtained by averaging 1000 acquired spectra in the MS mode in the mass range of 800 to 4000 $\mathrm{Da}$, and 2500 spectra in the MS/MS mode. Post source decay with the instrument operating at $1 \mathrm{keV}$ acceleration voltage was used for obtaining the MS/MS spectra of the selected 15 most intense peptide. Conversion of time of flight to mass (Da) for the monoisotopic ions, [M $+\mathrm{H}]^{+}$, was based on calibration of the instrument with a peptide standard calibration kit (Applied Biosystems). 
All MS/MS of peptides were queried against the SwissProt database using Mascot (Matrix Science, Inc. Boston, MA) search engine through GPS Explorer Software (Applied Biosystems) with a $50 \mathrm{ppm}$ for MS and 0.1 Da for MS/MS as error tolerance. Further search criteria included oxidation of methionine, formation of N-terminal pyro-glutamic acid as a variable modification, non-digestion enzyme for the UPLC fractions, and trypsin as digestion enzyme for the gel analysis. In both analyses the taxonomy was not specified. The signal to noise ratio for peak filtering was set to 20 for MS and 10 for MS/MS. Protein identification from gel bands was based on the combined MS and MS/MS spectra database search, while peptides identification leading to protein identification from the UPLC fractions were based on MS/MS spectra. Protein and peptides reported are with confidence of at least $95 \%$.

\subsection{Statistical Analyses}

A randomized split plot design was used to analyze the effects of milling treatment and storage and their interactions on the response variables (protein profile components). Analysis of variance (ANOVA) was carried out using PROC MIXED analysis [17]. The Bonferroni LSD test was used to determine statistically significant $(\mathrm{P}<$ 0.05) differences.

\section{RESULTS AND DISCUSSION}

Fresh Queso Fresco was made at DFF facilities and analyzed for compositional information. These cheeses displayed a range of $56.1 \%$ - 57.1\% moisture, $21.1 \%$ $22.1 \%$ fat, $14.8 \%$ - $16.0 \%$ protein, $2.52 \%$ - $2.66 \%$ lactose, and $2.45 \%$ salt. Notably, composition was fairly stable over the eight weeks of storage with only slight decreases measured in moisture and salt content $(\mathrm{P}<0.05)$. These results indicate that any milling treatment did not significantly impact cheese composition.

Two batches (B and C) of Queso Fresco were made, each using four different milling techniques (designated a, b, c, and d), to serve as duplicate sources of data. Analysis of the mass spectrometric data for all of the week one samples of QF $B$, regardless of milling technique, shows the presence of very little peptide in all cheeses, indicating that little protein degradation had occurred within the cheese. This result is also confirmed by the desitometric analysis of the protein bands in the SDS-PAGE gels run with samples from these cheeses (Figure 1). Overall intact protein concentrations were fairly high and did not vary much from sample to sample. Analysis of MS data for the QF C cheeses during week one shows similar behavior. Little peptide is observed in all cases, indicating in very little proteolysis has occurred. The QF C fc cheese shows slightly more peptide content in the initial sample (Figure 1), indicating that perhaps the milling technique utilized in this case (small blade in a meat grinder) may have slightly influenced the overall protein content. This was not observed in the QF B fc cheese sample, however, indicating that it is more likely that there may have been some initial contamination that led to slightly increased protein degradation in the week one sample.

In general, proteolysis in cheese results from bacterial proteases and peptidases, usually from starter cultures. Therefore, these results indicating minimal protein degradation are not surprising given that starter cultures were not employed in the make-procedures for these QF cheeses and pasteurized milk was used, limiting the overall bacterial population within the samples.

In both sets of QF B and C samples, a slight increase in the number of peptides in the mass spectra is observed after four weeks of aging. Tandem mass spectrometric analysis (Figure 2) of the peptides visible in the original mass spectra for the four weeks samples show the vast majority of the degradation products in these samples are $\beta$-casein fragments. This is also observed in the densitometry data, which shows that the concentration of intact $\beta$-casein decreases from the one week to four-week samples (Table 1). The densitometry data also indicates a decrease in the quantity of $\alpha_{\mathrm{s} 1}$-casein as well, but

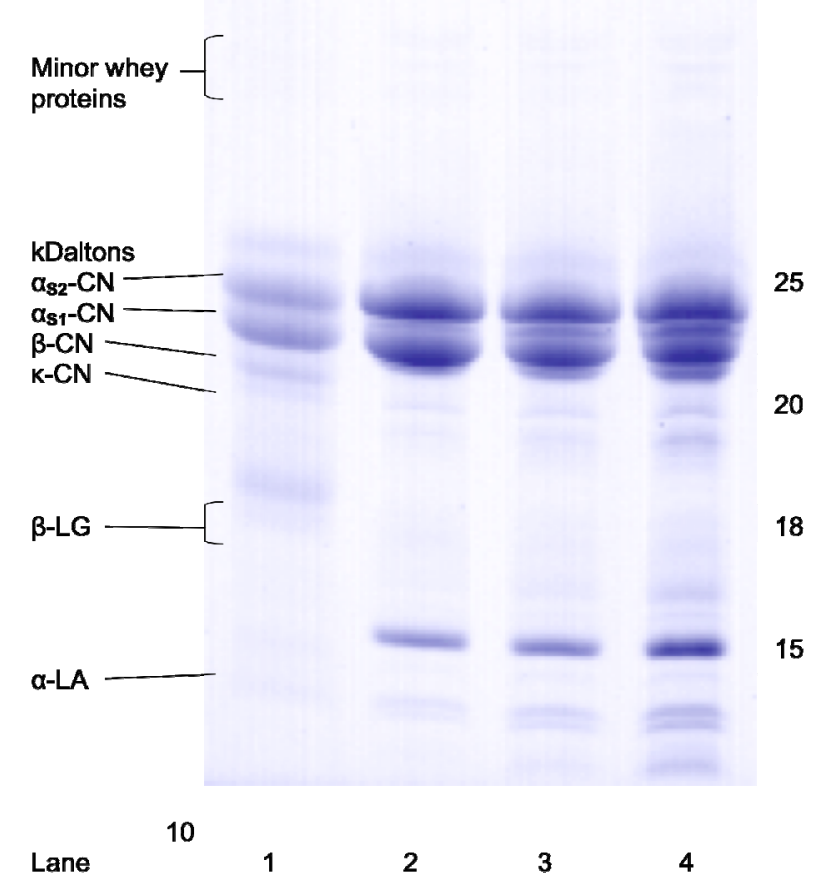

Figure 1. Protein profiles of bovine milk reference (lane 1) and Queso Fresco after 1, 4, and 8 weeks of storage at $4^{\circ} \mathrm{C}$ (lanes 2, 3 , and 4 , respectively); sample c is presented to illustrate pattern typical of all milling treatments. CN, casein; LA, lactalbumin; LG, lactoglobulin. 


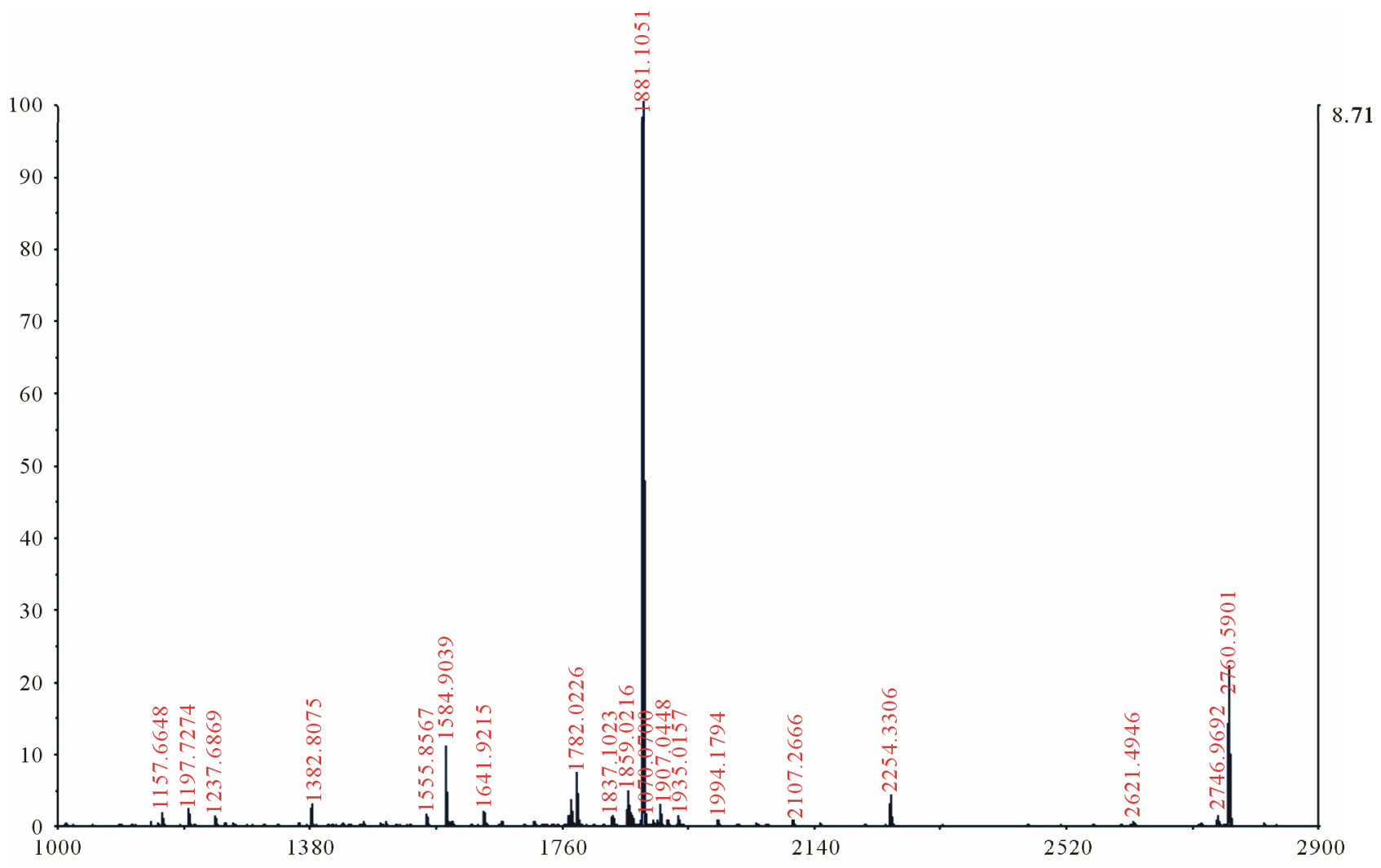

Figure 2. MALDI-TOF/TOF mass spectrometric data for QF C a1f sample.

Table 1. Densitometry measurements from SDS-PAGE showing decreases in $\alpha_{\mathrm{s} 1}$-casein and $\beta$-casein.

\begin{tabular}{|c|c|c|c|c|}
\hline \multirow{2}{*}{ Milling } & \multicolumn{2}{|c|}{$\alpha_{\mathrm{S} 1}-\mathrm{CN}(\%)$} & \multicolumn{2}{|c|}{$\beta$-CN (\%) } \\
\hline & wk 1 & wk 8 & wk 1 & wk 8 \\
\hline A & $34.7^{\mathrm{ab}}$ & $25.1^{\mathrm{d}}$ & $31.0^{\mathrm{a}}$ & $16.7^{\mathrm{cd}}$ \\
\hline B & $34.6^{\mathrm{ab}}$ & $27.0^{\mathrm{bcd}}$ & $30.0^{\mathrm{ab}}$ & $16.4^{\mathrm{cd}}$ \\
\hline $\mathrm{C}$ & $35.1^{\mathrm{a}}$ & $26.3^{\mathrm{cd}}$ & $29.9^{\mathrm{ab}}$ & $13.2^{\mathrm{d}}$ \\
\hline D & $33.4^{\mathrm{abc}}$ & $26.6^{\mathrm{cd}}$ & $30.2^{\mathrm{a}}$ & $18.6^{\mathrm{cd}}$ \\
\hline \multicolumn{5}{|c|}{ Standard Error } \\
\hline & \multicolumn{2}{|c|}{1.52} & \multicolumn{2}{|c|}{2.02} \\
\hline
\end{tabular}

smaller peptides corresponding to these degradation products were not readily observable.

After eight weeks of aging, mass spectrometric analysis showed more peptides present in the QF B and C samples. Further analysis of these peptides also indicated correlation to degradation products of $\beta$-casein. The data provided by densitometric analysis of the SDS-PAGE gels of QF B and C samples after eight weeks of aging also demonstrated a significant decrease in the concentration of $\beta$-casein compared to the one and four week samples (Table 1). The $\alpha_{\mathrm{s} 1}$-casein concentrations, however, were quite similar between the four and eight weeks samples, and once again, analysis by MS/MS did not show any significant $\alpha_{\mathrm{s} 1}$-casein degradation products. Interestingly, previous work has shown the degradation in cheese over time by bacterial species tends to be mostly focused on the digestion of $\alpha_{\mathrm{s} 1}$-casein rather than $\beta$-casein (M. Paul, unpublished results). Therefore, the absence of $\alpha_{\mathrm{s} 1}$-casein fragments in the MS data may be due to the overall concentration of the $\beta$-casein peptides being higher than those derived from $\alpha_{\mathrm{s} 1}$-casein, masking the presence of $\alpha_{\mathrm{s} 1}$-casein fragments, and making it more difficult to detect them. This may also result from the overall ability of $\beta$-casein fragments to ionize better, making them more easily detectable.

In all cases, changes in small peptide concentration among samples are observable only as they age over time; no significant differences are observed when comparing similarly aged samples that have been milled using different techniques. This indicates that the inclusion of a milling step does not have any major influence or provide any advantage in the overall protein breakdown during aging of these cheeses. Additionally, the extent of proteolysis that is observed is substantially less than that observed in the case of cheeses that have employed bacteria during cheese making (M. Paul, unpublished results). Therefore, the lack of starter cultures in these samples and the use of non-contaminated pasteurized 
milk leads to little proteolysis, and the limited peptide formation that is observed over time is most likely due to the eventual growth of spoilage bacteria.

\section{CONCLUSIONS}

In this study, the effects of various types of milling procedures on overall protein composition have been analyzed and shown to have little effect on model Queso Fresco cheeses. Protein degradation in these cheeses results mainly from the breakdown of $\beta$-casein after four to eight weeks of aging at $4^{\circ} \mathrm{C}$. Because very little protein breakdown is observed initially and starter cultures were not used in cheese making, this proteolysis is most likely due to the eventual occurrence of spoilage bacteria. This provides evidence that milling is not required in the production of Queso Fresco, and its incorporation as a step in the make-procedures may simply be an additional avenue for contamination while playing no essential role.

Traditional Queso Fresco is a fresh cheese made from raw milk that usually is consumed within a 14 days of production [3]. This does not adhere to US food guidelines, which require a 60-day holding period for fresh raw milk cheeses [18]. Aging of the model cheeses in this study over eight weeks shows minimal changes to the protein content. This study indicates that these Queso Fresco-like cheeses potentially can be stored longer than 14 days in the American household before consumption and still maintain their overall protein integrity, ultimately resulting in a fresher, longer lasting product. Further studies on the overall structural, sensorial and rheological effects of aging on these model cheeses are currently underway and will provide further evidence as to their utility as Queso Fresco-type cheeses that are safe and marketable for American consumers.

\section{ACKNOWLEDGEMENTS}

The authors would like to acknowledge Mr. Brien Sullivan for work with SDS-PAGE, Mr. James Shieh, Mr. Raymond Kwoczak, Ms. Latasha Leggett, and Ms. Danielle Tilman for their work in making the cheeses used for this study.

\section{REFERENCES}

[1] Lin, C.M., Zhang, L., Doyle, M.P. and Swaminathan, B. (2006) Comparison of media and sampling locations for isolation of Listeria monocytogenes in Queso Fresco cheese. Journal of Food Protection, 69, 2151-2156.

[2] Moreno-Enriquez, R.I., Garcia-Galaz, A., Acedo-Felix, E., Gonzalez-Rios, I.H., Call, J.E., Luchansky, J.B. and Diaz-Cinco, M.E. (2007) Prevalence, types, and geographical distribution of Listeria monocytogenes from a survey of retail Queso Fresco and associated cheese processing plants and dairy farms in Sonora, Mexico. Journal of Food Protection, 70, 2596-2601.
[3] Renye, J.A., Somkuti, G.A., Vallejo-Cordoba, B., Van Hekken, D.L. and Gonzalez-Cordova, A.F. (2008) Characterization of the microflora isolated from Queso Fresco made from raw and pasteurized milk. Journal of Food Safety, 28, 59-75. doi:10.1111/j.1745-4565.2007.00095.x

[4] Kasrazadeh, M. and Genigeorgis, C. (1994) Potential growth and control of Salmonella in Hispanic type soft cheese. International Journal of Food Microbiology, 22, 127-140. doi:10.1016/0168-1605(94)90137-6

[5] Kasrazadeh, M. and Genigeorgis, C. (1995) Potential growth and control of Escherichia coli O157:H7 in soft hispanic type cheese. International Journal of Food Microbiology, 25, 289-300. doi:10.1016/0168-1605(94)00089-O

[6] Guo, L., Van Hekken, D.L., Tomasula, P.M., Shieh, J. and Tunick, M.H. (2011) Effect of salt on the chemical, functional, and rheological properties of Queso Fresco during storage. International Dairy Journal, 21, 352-357. doi:10.1016/j.idairyj.2010.12.009

[7] Yun, J.J., Barbano, D.M. and Kindstedt, P.S. (1993) Mozzarella cheese: Impact of cooking temperature on chemical composition, proteolysis and functional properties. Journal of Dairy Science, 76, 3629-3638. doi:10.3168/jds.S0022-0302(93)77708-5

[8] Yun, J.J., Kiely, L.J., Paul, S.K. and Barbano, D.M. (1993) Mozzarella cheese: Impact of cooking temperature on chemical composition, proteolysis and functional properties. Journal of Dairy Science, 76, 3639-3647. doi:10.3168/jds.S0022-0302(93)77708-5

[9] Van Hekken, D.L., Drake, M.A., Corral, F.J., Prieto, V.M. and Gardea, A.A. (2006) Mexican chihuahua cheese: Sensory profiles of young cheese. Journal of Dairy Science, 89, 3729-3738. doi:10.3168/jds.S0022-0302(06)72414-6

[10] Van Hekken, D.L., Tunick, M.H., Tomasula, P.M., Molina-Corral, F.J. and Gardea, A.A. (2007) Mexican Queso Chihuahua: Rheology of fresh cheese. International Journal of Dairy Technology, 60, 5-12. doi:10.1111/j.1471-0307.2007.00291.x

[11] Paul, M. and Van Hekken, D.L. (2011) Short communication: Assessing antihypertensive activity in native and model Queso Fresco cheeses. Journal of Dairy Science, 94, 2280-2284. doi:10.3168/jds.2010-3852

[12] Tunick, M.H., Malin, E.L., Smith, P.W. and Holsinger, V.H. (1995) Effects of skim milk homogenization on proteolysis and rheology of Mozzarella cheese. International Dairy Journal, 5, 483-491. doi:10.1016/0958-6946(95)00026-Y

[13] Van Hekken, D.L., Tunick, M.H. and Park, Y.W. (2004) Rheological and proteolytic properties of monterey jack goat's milk cheese during aging. Journal of Agricultural and Food Chemistry, 52, 5372-5377. doi:10.1021/jf049918q

[14] Gomez-Ruiz, J.A., Ramos, M. and Recio, I. (2002) Angiotensin-converting enzyme-inhibitory peptides in Manchego cheeses manufactured with different starter cultures. International Dairy Journal, 12, 697-706.

[15] Meyer, J., Butikofer, U., Walther, B., Wechsler, D. and 
Sieber, R. (2009) Hot topic: Changes in angiotensinconverting enzyme inhibition and concentrations of the tripeptides Val-Pro-Pro and Ile-Pro-Pro during ripening of different Swiss cheese varieties. Journal of Dairy Science, 92, 826-836. doi:10.3168/jds.2008-1531

[16] Ryhanen, E.L., Pihlanto-Leppala, A. and Pahkala, E. (2001) A new type of ripened, low-fat cheese with bioac- tive properties. International Dairy Journal, 11, 441-447. doi:10.1016/S0958-6946(01)00079-6

[17] SAS Institute Inc. (2001) SAS for Windows Release 8.02. SAS Institute Inc., Cary.

[18] Code of Federal Regulations (2004) Cheeses and related cheese products. Code of Federal Regulations, Title 21, 2, Part 133. 